\title{
Impregnation of cinnamaldehyde into cassava starch biocomposite films using supercritical fluid technology for the development of food active packaging
}

\author{
Ana Cristina de Souza ${ }^{\mathrm{a}}$, Ana M.A. Dias ${ }^{\mathrm{b}}$, Hermínio C. Sousa $^{\mathrm{b}}$, Carmen C. Tadini ${ }^{\mathrm{a}, \mathrm{c}, *}$ \\ a Department of Chemical Engineering, EP, University of São Paulo, Av. Prof. Luciano Gualberto, Travessa 3, 380, 05508-010 São Paulo, SP, Brazil \\ b CIEPQPF, Chemical Engineering Department, FCTUC, University of Coimbra, Rua Sílvio Lima, Pólo II - Pinhal de Marrocos, 3030-790 Coimbra, Portugal \\ ' University of São Paulo, NAPAN, Food and Nutrition Research Center, Brazil
}

\section{A R T I C L E I N F O}

\section{Article history:}

Received 22 July 2013

Received in revised form 26 October 2013

Accepted 29 October 2013

Available online 5 November 2013

\section{Keywords:}

Cassava starch

Antimicrobial agent

Supercritical solvent impregnation

Food packaging

\begin{abstract}
A B S T R A C T
In this work, supercritical solvent impregnation (SSI) has been tested for the incorporation of natural compounds into biocomposite materials for food packaging. Cinnamaldehyde, with proved antimicrobial activity against fungi commonly found in bread products, was successfully impregnated on biocomposite cassava starch based materials using supercritical carbon dioxide as solvent. Different process experimental conditions were tested (pressure, impregnation time and depressurization rate) at a fixed temperature $\left(35^{\circ} \mathrm{C}\right)$ in order to study their influence on the amount of impregnated cinnamaldehyde as well as on the morphology of the films. Results showed that all conditions permitted to impregnate antimicrobial active amounts superior to those previously obtained using conventional incorporation methods. Moreover, a significant decrease of the equilibrium water vapor sorption capacity and water vapor permeability of the films was observed after SSI processing which is a clear advantage of the process, considering the envisaged applications.
\end{abstract}

(c) 2013 Elsevier Ltd. All rights reserved.

\section{Introduction}

To overcome current increased consumer demands for safer, environmental friendly and higher quality products, the development of biocomposite films for packaging materials, which can be used as substitutes for petrochemical based polymers, is an interesting alternative and showed to be a promising research field (Souza, Ditchfield, \& Tadini, 2010).

Although many types of biocomposite polymers are being industrially produced (PLA, PHA, PCL, PEA and others), polymers from agricultural sources, especially polysaccharides, such as starch or cellulose, are among the most studied.

Cassava starch has been extensively used to produce biocomposite films (Kechichian, Ditchfield, Veiga-Santos, \& Tadini, 2010; Mbeya, Hoppeb, \& Thomas, 2012; Müller, Yamashita, \& Laurindo, 2008; Paes, Yakimets, \& Mitchell, 2008; Souza et al., 2012; Souza, Goto, Mainardi, Coelho, \& Tadini, 2013; Veiga-Santos, Suzuki, Nery, Cereda, \& Scamparini, 2008) and also proved to be an interesting material for several food packaging applications, mainly

\footnotetext{
* Corresponding author at: Department of Chemical Engineering, EP, University of São Paulo, Av. Prof. Luciano Gualberto, Travessa 3, 380, 05508-010, São Paulo, SP, Brazil. Tel.: +55 113091 2258; fax: +55 1130912255 .

E-mail address: catadini@usp.br (C.C. Tadini).
}

because of their good film-forming properties. Films developed from starch are described as isotropic, odorless, tasteless, colorless, non-toxic and biologically degradable (Flores, Famá, Rojas, Goyanes, \& Gerschenson, 2007).

The production of biocomposites is another technological driver that permits to improve the tensile properties of biopolymer and biodegradable based materials. Also, and as previously reported, their barrier properties can be further improved by incorporating montmorillonite clay into the polymer matrix in order to reduce the gas permeability (Priolo, Gamboa, Holder, \& Grunlan, 2010; Souza et al., 2012, 2013). Nanoparticles like mineral clays are mainly composed of hydrated aluminosilicate with neutral or negative charged layers (Wilhelm, Sierakowski, Souza, \& Wypych, 2003).

Packaging is referred as active when it performs some desired role in food preservation other than providing an inert barrier to external conditions. It permits to change the condition of the packaged food to extend its shelf life or to improve safety or sensory properties, while maintaining its quality (Souza et al., 2010). Biocomposite films carrying natural additives, such as antimicrobial agents, could be considered an emergent tendency of functional food packaging.

The antibacterial and antifungal activities of essential oils are well known and present clear advantages because of their greater activity when compared with the effects of the individual active compounds, probably due to the synergistic effects 
(Bakkali, Averbeck, Averbeck, \& Idaomar, 2008; Du Plooy, Regnier, \& Combrinck, 2009).

Cinnamon bark essential oil, mainly constituted by cinnamaldehyde $(\mathrm{CN})$, showed a strong antimicrobial activity against Pseudomonas putida strain isolated from meat (Oussalah, Caillet, Saucier, \& Lacroix, 2006). Scanning electron microscopic observations revealed that the antimicrobial activity of cinnamaldehyde is bacteriocidal since bacterial cells suffered severe damages in their surface structure (Kim, Park, \& Park, 2004). Nielsen and Rios (2000) demonstrated the high activity of essential oil against the most important spoilage fungi of bread, whereas Oussalah, Caillet, Saucier, and Lacroix (2007) showed that the essential oil of Cinnamomun cassia was the most active against pathogenic bacteria.

The incorporation of essential oils into viscous biopolymer solutions (that are normally used to prepare biocomposite and active films by the conventional solvent casting method) has some drawbacks mainly due to the oil hydrophobic character that makes difficult to obtain a homogeneous material (Kechichian et al., 2010; Mayachiew \& Devashastin, 2010; Mayachiew, Devashastin, Mackey, \& Niranjan, 2010; Seydim \& Sarikus, 2006; Souza et al., 2013). In these cases supercritical solvent impregnation (SSI) method can represent an efficient and advantageous alternative. This technique has been largely used in the development of materials for applications in the biomedical field mostly to prepare improved sustained drug delivery devices (Braga et al., 2008; Costa et al., 2010a, 2010b; Dias et al., 2011; Natu, Gil, \& Sousa, 2008) and scaffolds with different porosities for tissue engineering applications (Reverchon \& Cardea, 2012). Applications of this new technique in antimicrobial packaging are quite scarce (Bierhalz, Silva, Sousa, Braga, \& Kieckbusch, 2013; Sonkaew, Sane, \& Suppakul, 2012).

Among the main advantages of the SSI technique it can be referred that: (i) it permits the impregnation of a large number of different natural and synthetic based polymers if they swell when in contact with supercritical carbon dioxide $\left(\mathrm{scCO}_{2}\right)$; (ii) it is particularly advantageous to impregnate hydrophobic molecules, as is the case of essential oils; (iii) solute loading and depth of impregnation can be tuned by changing process conditions; (iv) it originates final products that are free from organic solvent residues since $\mathrm{scCO}_{2}$ is released as a gas after depressurization; and finally (v) the technique permits to work at relatively mild conditions in an oxygen free environment which is often desirable when the objective is to impregnate natural based compounds with biological activity.

In this way, the main goal of this work was the development and characterization of active starch based films to be used for food packaging purposes. Films were impregnated with cinnamaldehyde, an antimicrobial agent that inhibit the proliferation of Penicillium commune and Eurotium amstelodami, fungi commonly found in bread products, using $\mathrm{scCO}_{2}$ as solvent at different process conditions. The antimicrobial agent was also incorporated in film matrix by the conventional solvent casting method for comparison. The antimicrobial quantification and other important properties for food packaging applications such as the equilibrium water sorption capacity and water vapor permeability of $\mathrm{scCO}_{2}$ processed and non-processed films were also evaluated.

\section{Materials and methods}

\subsection{Materials}

Native cassava starch, Amilogill ${ }^{\circledR} 1500$, kindly supplied by Cargill Agrícola, Brazil (amylose: $19.7 \mathrm{~g} / 100 \mathrm{~g}$; amylopectin: $80.3 \mathrm{~g} / 100 \mathrm{~g}$; maximum moisture: $14.0 \mathrm{~g} / 100 \mathrm{~g}$ ) was used as the film forming component to provide a continuous biocomposite film matrix. Glycerol (Synth, Brazil) was added as plasticizer and natural
Na-montmorillonite clay (commercial product Argel T, Bentonit União, Brazil, used as received) was used as filler. Pure cinnamaldehyde (Synth, Portugal) was used as antimicrobial agent. Distilled water and ethanol (95\%, Synth, Brazil) were used as solvents for the filmogenic solutions. Carbon dioxide (99.998\%, White Martins, Portugal) was employed as solvent in the SSI experiments. Silica gel (Sigma-Aldrich, Brazil), potassium sulfate (99\%, Sigma-Aldrich, Portugal) and sodium chloride (99.5\%, Sigma-Aldrich, Brazil) were used to create the controlled relative humidity $(\mathrm{RH})$ conditions.

\subsection{Film preparation}

Firstly, Biocomposite Active Films (BAF) were produced by the solvent casting method: the filmogenic solution was prepared by mixing $0.8 \mathrm{~g}$ of cinnamaldehyde with $1.0 \mathrm{~g}$ of glycerol at $38 \pm 2{ }^{\circ} \mathrm{C}$, using a magnetic stirrer. This mixture was further homogenized with a solution previously prepared according to Souza et al. (2012) and Souza et al. (2013), with $0.1 \mathrm{~g}$ of clay nanoparticles, $5.0 \mathrm{~g}$ of cassava starch and $95 \mathrm{~g}$ of distilled water. After cooling, this solution was diluted with $14.25 \mathrm{~g}$ of ethanol and poured onto cylindrical plates and dried at $(35 \pm 2)^{\circ} \mathrm{C}$ for $(18-24) \mathrm{h}$, in an oven with forced air circulation (Nova Ética, series N480, Brazil). The maximum employed amount of antimicrobial agent was defined in previous work $(0.080 \mathrm{~g} / 100 \mathrm{~g}$ of filmogenic solution) and its incorporation was only possible using sucrose ester of fatty acids, an emulsifier specific for oil/water emulsions in order to avoid a phase separation, corresponding to 0.080 for emulsifier content/essential oil content proportion (Souza et al., 2013).

For SSI experiments, Biocomposite Films (BF) were also prepared, according to same procedure using $1.5 \mathrm{~g}$ of glycerol, by solvent casting method, without antimicrobial agent. The BF were than impregnated with cinnamaldehyde using the SSI technique to produce BAF.

\subsection{Supercritical solvent impregnation (SSI) experiments}

The supercritical carbon dioxide $\left(\mathrm{scCO}_{2}\right)$ high pressure equipment used in this work, described in detail by Sousa, Gil, Leite, Duarte, and Duarte (2006), is comprised of a compressed $\mathrm{CO}_{2}$ liquid pump, a sealed high pressure stainless steel vessel with sapphire windows (with an internal volume of $\sim 10 \mathrm{~cm}^{3}$ ), a temperaturecontrolled bath $\left( \pm 0.1^{\circ} \mathrm{C}\right)$, a pressure transducer and a magnetic stirring plate placed under the cell (working at $300 \mathrm{rpm}$ ). Briefly, an experimental SSI assay, at batch mode, consists in introducing liquefied $\mathrm{CO}_{2}$ into the thermostatized high pressure cell until the desired operational pressure is achieved. The cell was previously loaded with squared film samples to be impregnated ( 6 samples of $1.2 \mathrm{~cm} \times 1.2 \mathrm{~cm}$ ) fixed by stainless steel supports and with $0.20 \mathrm{~mL}$ of cinnamaldehyde. The employed amount of antimicrobial agent was calculated taking into account the solubility of the antimicrobial agent at the operational conditions (Baseri, Haghighi-Asl, \& Lotfollahi, 2010), the volume of the cell and the weight of the films (approximately $50 \mathrm{mg}$ for each sample). A magnetic stirrer was also placed into the cell to promote the solubility of cinnamaldehyde in the $\mathrm{scCO}_{2}$ phase. The operational conditions tested were (150 and 250 ) bar at $35^{\circ} \mathrm{C}$ and for two impregnation times ( 3 and 15) h and at two depressurization rates (1 and 10) bar min ${ }^{-1}$ (Table 1 ). These working conditions were previously defined in the sample films using only $\mathrm{ScCO}_{2}$.

Before impregnation tests, all samples were stored at a controlled relative humidity ( $\mathrm{RH}$ ) of $75 \%$. After the pre-established impregnation time (the period in which the antimicrobial agent and the films are in direct contact under pressure), the system was then depressurized and the impregnated films were stored at $-4{ }^{\circ} \mathrm{C}$ to avoid cinnamaldehyde sublimation until further analyses. In order to confirm their stability when subjected to different process 
Table 1

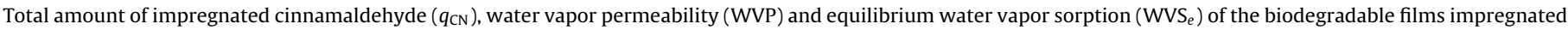
with cinnamaldehyde at different process conditions $\left(P, t_{i}, d_{r}\right)$ of Supercritical Solvent Impregnation (SSI) experiments at the temperature of $35^{\circ} \mathrm{C}$.

\begin{tabular}{|c|c|c|c|c|c|}
\hline$P($ bar $)$ & $t_{i}(\mathrm{~h})$ & $d_{r}\left(\right.$ bar $\left.\min ^{-1}\right)$ & $q_{\mathrm{CN}}\left(\mathrm{mg}_{\mathrm{CN}} \mathrm{g}_{\mathrm{film}}{ }^{-1}\right)$ & WVP $\left(\mathrm{g} \mathrm{mm} \mathrm{m}^{-2}\right.$ day $\left.^{-1} \mathrm{kPa}^{-1}\right)$ & $\mathrm{WVS}_{e}(\%)$ \\
\hline 150 & 3 & 1 & $1.29 \pm 0.13^{1 \mathrm{aA}}$ & $5.28 \pm 0.48^{1 \mathrm{aA}}$ & $46.75 \pm 0.98^{1 \mathrm{aA}}$ \\
\hline 150 & 3 & 10 & $1.01 \pm 0.31^{1 \mathrm{aB}}$ & $5.19 \pm 0.41^{1 \mathrm{aA}}$ & $56.40 \pm 5.19^{1 \mathrm{aB}}$ \\
\hline 150 & 15 & 1 & $1.19 \pm 0.16^{1 \mathrm{aA}}$ & $5.57 \pm 0.55^{1 \mathrm{aA}}$ & $43.29 \pm 5.43^{2 \mathrm{aA}}$ \\
\hline 150 & 15 & 10 & $1.22 \pm 0.09^{1 \mathrm{aB}}$ & $5.16 \pm 0.41^{1 \mathrm{aA}}$ & $48.53 \pm 1.41^{2 \mathrm{aB}}$ \\
\hline 250 & 3 & 1 & $1.37 \pm 0.24^{1 \mathrm{bA}}$ & $6.22 \pm 0.27^{2 \mathrm{bA}}$ & $49.34 \pm 1.35^{1 \mathrm{aA}}$ \\
\hline 250 & 3 & 10 & $1.74 \pm 0.19^{1 \mathrm{cB}}$ & $6.01 \pm 0.51^{2 \mathrm{bA}}$ & $58.66 \pm 1.82^{1 \mathrm{aB}}$ \\
\hline 250 & 15 & 1 & $0.99 \pm 0.23^{1 \mathrm{bA}}$ & $5.64 \pm 0.69^{3 \mathrm{aA}}$ & $36.59 \pm 0.71^{2 \mathrm{aA}}$ \\
\hline 250 & 15 & 10 & $2.50 \pm 0.20^{1 \mathrm{cB}}$ & $4.09 \pm 0.84^{3 \mathrm{aA}}$ & $47.62 \pm 5.94^{2 \mathrm{aB}}$ \\
\hline Tukey HSD & & & 0.25 & 0.62 & 3.95 \\
\hline
\end{tabular}

$P$ : pressure (bar).

$t_{i}$ : impregnation time $(\mathrm{h})$.

$d_{r}$ : depressurization rates (bar $\min ^{-1}$ ).

Means with the same uppercase, in the same column, at the same $d_{r}$, are not significantly different $(P<0.05)$.

Means with the same number, in the same column, at the same $t_{i}$, are not significantly different $(P<0.05)$.

a Means with the same lowercase, in the same column, at the same $P$, are not significantly different $(P<0.05)$.

conditions (different pressures and depressurization rates), samples of $\mathrm{BF}$ were processed with $\mathrm{scCO}_{2}$ without using antimicrobial agent.

\subsection{Antimicrobial agent quantification}

The amount of antimicrobial agent impregnated in the films processed at different tested conditions was quantified, in duplicate, by UV-vis spectroscopy (using a spectrophotometer JASCO, model 530, Japan) measuring at $289 \mathrm{~nm}$, corresponding to the maximum absorption wavelength of cinnamaldehyde, and using a pre-determined calibration curve. Quantification was carried out at room temperature $\left(\sim 25^{\circ} \mathrm{C}\right)$ with the films immersed in Milli-Q water $(150 \mathrm{~mL})$ for $3 \mathrm{~h}$, which was enough to guarantee that the impregnated antimicrobial agent was completely released from the films. This method just intended overall quantification of the total amount of $\mathrm{CN}$ impregnated into the cassava starch films for each experimental condition tested. Further studies should that into account real conditions that may be found considering the envisaged applications.

\subsection{Fourier transform infrared (FTIR) spectroscopy}

In order to verify the incorporation of cinnamaldehyde in the films, FTIR spectroscopy (Jasco, model 4200, UK) was performed at 128 scans with a $4 \mathrm{~cm}^{-1}$ resolution, between (500 and 4000$) \mathrm{cm}^{-1}$, and using a Golden Gate Single Reflection Diamond ATR accessory. Samples were analyzed before and after the impregnation experiments.

\subsection{Scanning electron microscopy (SEM)}

Samples were mounted on aluminum stubs, coated with a thin layer of gold (approximately $300 \AA$ ) and observed on Scanning Electron Microscope at an accelerate voltage of $5.00 \mathrm{kV}$ (Philips, model $\mathrm{XL}-30 \mathrm{FEG}$ ) and at an accelerate voltage of $10.00 \mathrm{kV}$ (Jeol, model JSM-5310).

\subsection{Water vapor permeability (WVP)}

The water vapor transmission rate (WVTR) was measured by a gravimetric method based on the ASTM E96/E96M-10 (2010), using the Desiccant Method, with modifications for hydrophilic edible films, proposed by McHugh, Avena-Bustillos, and Krochta (1993). The water vapor permeability (WVP) $\left(\mathrm{g} \mathrm{mm} \mathrm{m}^{-2} \mathrm{day}^{-1} \mathrm{kPa}^{-1}\right)$ was determined as the rate of water vapor transmission (WVTR) through a unit area of flat material of unit thickness induced by the unit vapor pressure difference between two surfaces, under specified humidity and temperature conditions. The thickness of the films was measured using a flat parallel surface micrometer (MITUTOYO SulAmericana Ltda., model 103-137, Brazil, precision $0.002 \mathrm{~mm}$ ), at five random positions of each sample. A test tube was covered with the film sample and sealed with a holed screw cap (circular opening of $0.6 \mathrm{~cm}^{2}$ ). Silica gel was placed inside the test tube and sodium chloride saturated solution (75\% relative humidity, $\mathrm{RH}$ ) was used in the desiccators to maintain the required $\mathrm{RH}$ gradient across the film. The system was maintained inside a bath at $23{ }^{\circ} \mathrm{C}$. Two cells without silica gel were prepared and submitted to the same conditions to account for weight changes occurring in the film, since it is a highly hydrophilic material. The RH inside the test tube was always lower than outside, and the water vapor transmission was determined from the weight gain of the test tube. After steady state conditions were reached (about $2 \mathrm{~h}$ ), weight measurements were made over $48 \mathrm{~h}$ at fixed time intervals. WVP was calculated according Eq. (1):

$\mathrm{WVP}=\left(\frac{w}{\theta}\right) \times\left[\frac{24 \times \delta}{A \times \Delta p}\right]$

wherein WVP is the water vapor permeability ( $\left.\mathrm{g} \mathrm{mm} \mathrm{m}^{-2} \mathrm{~d}^{-1} \mathrm{kPa}^{-1}\right) ; w$ is the weight gain (from the straight line) $(\mathrm{g}) ; \theta$ is the time during which $w$ occurred $(\mathrm{h}) ; \delta$ is the average film thickness [mm]; $A$ is the test area (cell top area) $\left(\mathrm{m}^{2}\right)$ and $\Delta p$ is the vapor pressure difference $(\mathrm{kPa})$. All samples were evaluated in triplicate.

\subsection{Water vapor sorption (WVS)}

Films were cut into quadrangular $(1 \mathrm{~cm} \times 1 \mathrm{~cm})$ samples and dried at $40^{\circ} \mathrm{C}$ until constant weight was achieved. Dried samples were then exposed to an atmosphere of $95 \% \mathrm{RH}$ (at $23^{\circ} \mathrm{C}$ ) in a desiccator containing a potassium sulfate saturated solution. Samples were weighed at pre-determined time intervals and the water vapor sorption loading was calculated as:

$\mathrm{WVS}=\left(\frac{w_{t}-w_{0}}{w_{0}}\right) \times 100$

wherein: $w_{0}(\mathrm{~g})$ and $w_{t}(\mathrm{~g})$ are the sample weight at the beginning of the experiment (dried) and at time $t$, respectively. Films impregnated with cinnamaldehyde at different conditions were submitted to tests in triplicate and non processed films were also tested for comparison. 


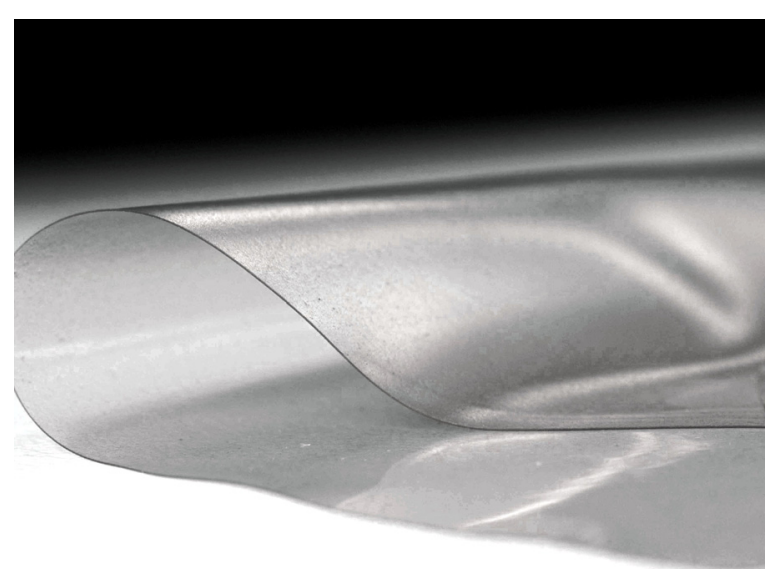

Fig. 1. Cassava starch film incorporated with antimicrobial agent by casting (photo credit: Eduardo de Oliveira, FAPESP).

\subsection{Water contact angle}

Static contact angle measurements were performed using milli$\mathrm{Q}$ water at room temperature $\left(\sim 23^{\circ} \mathrm{C}\right)$, and using the sessile-drop method $(10 \mu \mathrm{L})$ (Dataphysics Instruments, OCA 20, Germany).

\subsection{Thermal analysis}

Thermal events were determined by differential scanning calorimetry (TA Instruments, Q200 MDSC, USA) at the temperaturemodulated mode (modulate $\pm 0.32{ }^{\circ} \mathrm{C}$ every $60 \mathrm{~s}$ ). Calibration was performed with indium and sapphire. Non-processed and $\mathrm{scCO}_{2}$ processed samples ( $\sim 7 \mathrm{mg}$ weight) were placed in aluminum pans and submitted to a temperature program, under nitrogen atmosphere in dynamic mode $\left(50 \mathrm{mLmin}^{-1}\right)$. In the first scan, after cooling the sample at $10^{\circ} \mathrm{C} \mathrm{min}^{-1}$ up to $-60^{\circ} \mathrm{C}$, it was submitted to heating at $10^{\circ} \mathrm{C} \mathrm{min}^{-1}$ until $100^{\circ} \mathrm{C}$. The second scan was between $-60^{\circ} \mathrm{C}$ and $250^{\circ} \mathrm{C}$, at the same cooling and heating rates. The glass transition temperature $(\mathrm{Tg})\left({ }^{\circ} \mathrm{C}\right)$ was calculated as the middle point between the onset and end temperatures caused by the discontinuity of sample specific heat. Two replicate runs were carried out for each sample.

\subsection{Statistical analysis}

Analysis of variance (ANOVA) was applied on the results using the statistical program Statgraphics Centurion v.15.0 (StatPoint ${ }^{\circledR}$, Inc., USA) and the Tukey test was used to evaluate average differences (at a $95 \%$ of confidence interval).

\section{Results and discussion}

Biocomposite Active Films (BAF) produced by the traditional method (casting) were homogeneous, transparent and flexible, and their surfaces were smooth, without pores and cracks, or insoluble particles (Fig. 1).

\subsection{Antimicrobial agent quantification}

The amount of cinnamaldehyde $\left(q_{\mathrm{CN}}\right)$ impregnated into cassava starch films at different process conditions is presented in Table 1 and is represented in terms of mass of impregnated CN per mass of cassava films after impregnation $\left(\mathrm{g}_{\mathrm{CN}} / \mathrm{g}_{\mathrm{film}}\right)$. The values represent the total released amount for a period of $3 \mathrm{~h}$ after immersion of the loaded samples into water. After this period, samples were immersed in fresh water to guarantee that all the impregnated $\mathrm{CN}$ was released from the films. ANOVA was applied in order to verify the influence of the tested process parameters (pressure, $P$, impregnation time, $t_{i}$ and depressurization rate, $d_{r}$ ) on the amount of impregnated $\mathrm{CN}$ and indicated that the impregnation time did not significantly influenced the results $(P>0.05)$. The obtained results show that at lower pressure (Table 1 ) the amount of $\mathrm{CN}$ impregnated into cassava starch films is similar, independently of the experimental conditions used, and varied from $(1.01 \pm 0.31) \mathrm{mg}_{\mathrm{CN}} / \mathrm{g}_{\text {film }}$ for the higher depressurization rate up to $(1.29 \pm 0.13) \mathrm{mg}_{\mathrm{CN}} / \mathrm{g}_{\text {film }}$ for the lower depressurization rate. However, this tendency was not observed at 250 bar and the highest $q_{\mathrm{CN}}$ value $(2.50 \pm 0.20) \mathrm{mg}_{\mathrm{CN}} / \mathrm{g}_{\text {film }}$ was observed with a depressurization rate of the $10 \mathrm{bar} \mathrm{min}^{-1}$, during $15 \mathrm{~h}$ of processing.

All these results indicate that the SSI of CN into cassava starch films is mainly dependent on its solubility in $\mathrm{scCO}_{2}$ which is higher at 250 bar. According to data previously reported in literature (Baseri et al., 2010), the solubility of $\mathrm{CN}$ increases with pressure about $40 \%$ when the solvent density increases from $840 \mathrm{~kg} \mathrm{~m}^{-3}$ to $920 \mathrm{~kg} \mathrm{~m}^{-3}$ (values similar those used in this work, which were $815 \mathrm{~kg} \mathrm{~m}^{-3}$ at 150 bar and $901 \mathrm{~kg} \mathrm{~m}^{-3}$ at 250 bar, both at $35^{\circ} \mathrm{C}$ ), data taken from NIST (2013). In addition, at higher pressures, the $\mathrm{scCO}_{2}$ swelling and plasticization of most polymers is usually favored and this will also improve the impregnation/loading efficiency (Kazarian, 2000; Kikic \& Vecchione, 2003). During depressurization, the solubility of $\mathrm{CN}$ decreases (which may favor $\mathrm{CN}$-polymer affinity) and $\mathrm{scCO}_{2}$ changes to a gas, and is vented, leaving the antimicrobial agent trapped inside the matrix. Moreover, the lower $q_{\mathrm{CN}}$ observed at lower depressurization rates (for both pressures) is because, at this condition, part of the $\mathrm{CN}$ trapped into the matrix re-solubilize into $\mathrm{scCO}_{2}$ and escapes with it decreasing the loading efficiency.

Finally, and as expected, at higher depressurization rates, the use of higher processing times improved the sorption capacity of $\mathrm{scCO}_{2}$ into the matrix and consequently the $q_{\mathrm{CN}}$. Therefore it is possible to control the amount of $\mathrm{CN}$ impregnated into cassava starch films by changing the impregnation process conditions. In this work and for the tested experimental conditions, it was possible to increase the amount of $q_{\mathrm{CN}}$ from $(0.99 \pm 0.23)$ to $(2.50 \pm 0.20) \mathrm{mg}_{\mathrm{CN}} / \mathrm{g}_{\text {film }}$ by increasing the depressurization rate.

The general tendency is that lower pressure and higher depressurization rates lead to lower impregnated amounts while higher pressure and higher depressurization rates favor $\mathrm{CN}$ loading. However, the results obtained in this work are already promising since it was found that the maximum $q_{\mathrm{CN}}$ obtained by the incorporation of this antimicrobial agent into the filmogenic solution of the film produced by casting technique was $(1.19 \pm 0.02) \mathrm{mg}_{\mathrm{CN}} / \mathrm{g}_{\text {film }}$ (Souza et al., 2013), indicating that the SSI method can represent an effective alternative if higher impregnated amounts are required. Moreover, in the same work, authors concluded that samples containing $1.19 \mathrm{mg}_{\mathrm{CN}} / \mathrm{g}_{\text {film }}$ could inhibit selected fungi (Penicillium commune and Eurotium amstelodami), commonly found in bread products. In this way, it can be concluded that all conditions studied in the present work were able to provide films that are active against the referred microorganisms.

\subsection{Fourier transform infrared (FTIR) spectroscopy}

The incorporation of $\mathrm{CN}$ into the films was also confirmed by FTIR-ATR as shown in Fig. 2. The spectra of impregnated and of non-impregnated starch based films show significant differences in the range (1200-1400) $\mathrm{cm}^{-1}$ and $(1600-1700) \mathrm{cm}^{-1}$ attributed to vibrations of the aromatic ring and to the aldehyde group of cinnamaldehyde, confirming that the antimicrobial agent was effectively impregnated into the films. As expected, $\mathrm{scCO}_{2}$ did not induce any chemical modification to the matrix and therefore the spectra of non-processed and $\mathrm{scCO}_{2}$ processed cassava starch films are similar. 


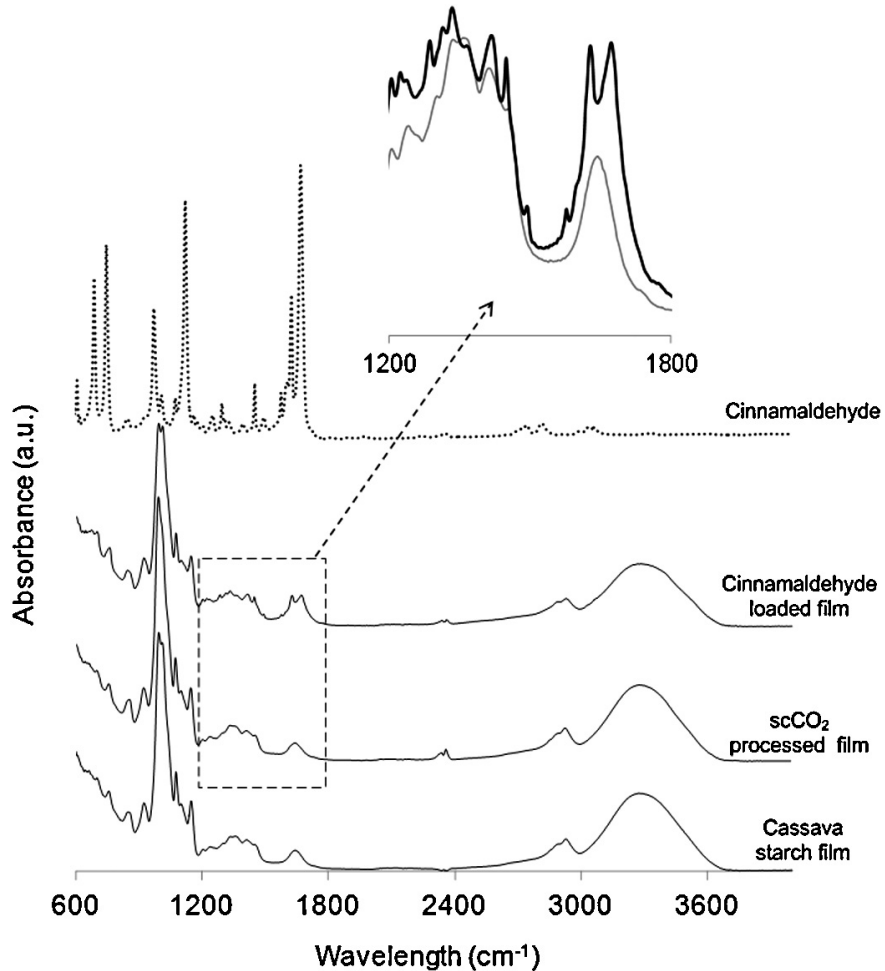

Fig. 2. FTIR-ATR spectra of cassava starch films impregnated with and without cinnamaldehyde processed at 250 bar during $15 \mathrm{~h}$ and at a depressurization rate of 10 bar min $^{-1}$ in comparison with non-processed films and the spectrum of pure cinnamaldehyde.

\subsection{Scanning electron microscopy (SEM)}

It was also observed by SEM that the process do not alter/damage the polymer structure. The surface and cross-section images of non-processed and $\mathrm{CN}$-impregnated films are shown in Fig. 3, where it is possible to observe some changes in the film surface, probably due to deposition of $\mathrm{CN}$ that may occur during depressurization, but the inexistence of bubbles or any other deformation in both cases.

\subsection{Water vapor permeability (WVP)}

ANOVA applied on the water vapor permeability (WVP) results presented in Table 1 indicated that only the interaction of pressure $(P)$ with impregnation time $\left(t_{i}\right)$ influenced significantly this property. At $3 \mathrm{~h}$ of $t_{i}$ the WVP increased as pressure increased, whereas at $15 \mathrm{~h}$ of $t_{i}$ the WVP decreased as pressure increased. Films processed with $\mathrm{scCO}_{2}$ without cinnamaldehyde at 150 bar (Table 2) present WVP values that varied from $(11.64 \pm 0.50) \mathrm{g} \mathrm{mm} \mathrm{m}^{-2}$ day $^{-1} \mathrm{kPa}^{-1}$ to $\quad(13.01 \pm 0.44) \mathrm{g} \mathrm{mm} \mathrm{m}^{-2} \mathrm{day}^{-1} \mathrm{kPa}^{-1}$. These values are similar to those obtained for films processed with $\mathrm{ScCO}_{2}$ without cinnamaldehyde at $250 \mathrm{bar}$ (Table 2) that varied from $(12.17 \pm 1.04) \mathrm{g} \mathrm{mm} \mathrm{m}^{-2} \mathrm{day}^{-1} \mathrm{kPa}^{-1}$ to $(13.03 \pm 1.19) \mathrm{g} \mathrm{mm} \mathrm{m}^{-2} \mathrm{day}^{-1} \mathrm{kPa}^{-1}$. For comparison, ANOVA indicated that the impregnation processing significantly decreased the WVP from average value of $(5.40 \pm 0.65) \mathrm{g} \mathrm{mm} \mathrm{m}^{-2} \mathrm{day}^{-1} \mathrm{kPa}^{-1}$ for films with cinnamaldehyde, to $(12.63 \pm 0.49) \mathrm{g} \mathrm{mm} \mathrm{m}^{-2}$ day $^{-1} \mathrm{kPa}^{-1}$ for $\mathrm{scCO}_{2}$ processed films without cinnamaldehyde. These results indicate that the treatment with $\mathrm{scCO}_{2}$ caused an increase in WVP values, which was equal to $(10.09 \pm 0.35) \mathrm{g} \mathrm{mm} \mathrm{m}^{-2}$ day $^{-1} \mathrm{kPa}^{-1}$ before processing. This may be probably due to the formation of micro-porosities

Cassava starch films processed with $\mathrm{scCO}_{2}$ at 250 bar for $15 \mathrm{~h}$ and higher depressurization rate (10 bar. $\min ^{-1}$ )
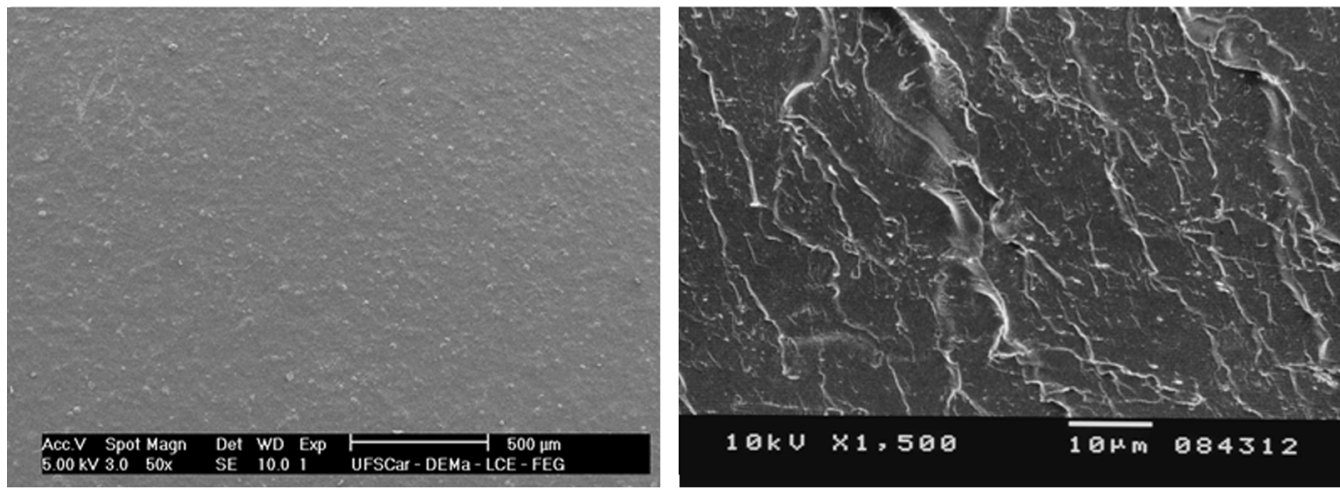

Cassava starch films loaded with cinnamaldehyde at 250 bar for $15 \mathrm{~h}$ and higher depressurization rate (10 bar.min $\left.{ }^{-1}\right)$
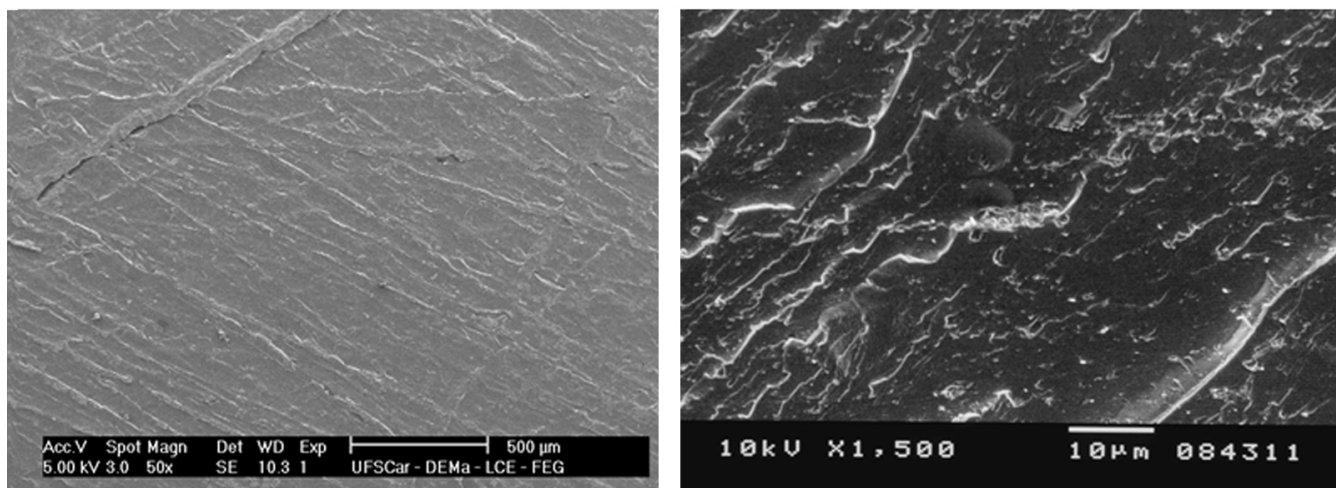

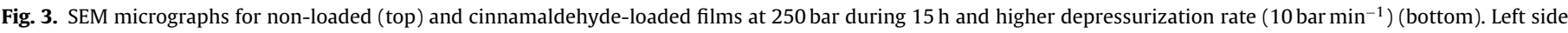
figures represent surfaces while right side figures represent cross sections. 
Table 2

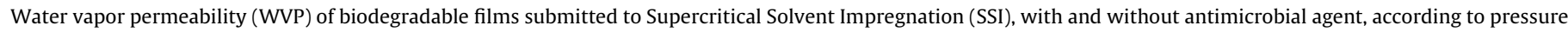
$(P)$, time of impregnation $\left(t_{i}\right)$ and depressurization rate $\left(d_{r}\right)$.

\begin{tabular}{|c|c|c|c|c|c|c|c|c|c|}
\hline & \multicolumn{8}{|c|}{ WVP ( $\left.\mathrm{g} \mathrm{mm} \mathrm{m}^{-2} \mathrm{day}^{-1} \mathrm{kPa}^{-1}\right)$} & \multirow[t]{2}{*}{ Tukey HSD ${ }^{\mathrm{a}}$} \\
\hline$P$ (bar) & \multicolumn{4}{|c|}{150} & \multicolumn{4}{|c|}{250} & \\
\hline$t_{i}(\mathrm{~h})$ & 3 & & 15 & & 3 & & 15 & & \\
\hline$d_{r}\left(\right.$ bar min $\left.^{-1}\right)$ & 1 & 10 & 1 & 10 & 1 & 10 & 1 & 10 & \\
\hline With & $5.28 \pm 0.48^{\mathrm{aA}}$ & $5.19 \pm 0.41^{\mathrm{aA}}$ & $5.57 \pm 0.55^{\mathrm{aA}}$ & $5.16 \pm 0.41^{\mathrm{aA}}$ & $6.22 \pm 0.27^{\mathrm{aA}}$ & $6.01 \pm 0.51^{\mathrm{aA}}$ & $5.64 \pm 0.69^{\mathrm{aA}}$ & $4.09 \pm 0.84^{\mathrm{aA}}$ & 0.58 \\
\hline Without & $13.01 \pm 0.44^{\mathrm{aB}}$ & $12.81 \pm 1.07^{\mathrm{aB}}$ & $11.64 \pm 0.50^{\mathrm{aB}}$ & $12.96 \pm 1.13^{\mathrm{aB}}$ & $12.57 \pm 0.86^{\mathrm{aB}}$ & $12.88 \pm 1.24^{\mathrm{aB}}$ & $12.17 \pm 1.04^{\mathrm{aB}}$ & $13.03 \pm 1.19^{\mathrm{aB}}$ & \\
\hline
\end{tabular}

$P$ : pressure (bar).

$t_{i:}$ impregnation time (h).

$d_{r}$ : depressurization rates ( bar $\mathrm{min}^{-1}$ ).

Means with the same uppercase, in the same column are not significantly different $(P<0.05)$.

a Means with the same lowercase, in the same row, are not significantly different $(P<0.05)$.

(not detected by SEM) in the polymer structure caused by the dissolution/release of $\mathrm{scCO}_{2}$ into/from the film, originating materials that are more permeable to the water vapor.

As already mentioned, ANOVA applied on these results indicated that the tested process conditions did not significantly affect $(P>0.05)$ the WVP of films impregnated with cinnamaldehyde. However, a significant and positive influence of the process on the WVP of the films was observed after cinnamaldehyde incorporation by SSI since impregnated films present values that are almost half that observed for films without impregnation. It can also be noticed that the different amounts of loaded cinnamaldehyde resulted in a significant decrease in WVP of the films. The WVP of the films loaded with the antimicrobial agent by the conventional methodology was equal to $(9.78 \pm 0.45) \mathrm{g} \mathrm{mm} \mathrm{m}^{-2} \mathrm{day}^{-1} \mathrm{kPa}^{-1}$, which is almost $140 \%$ higher than the value obtained by the SSI method (at 250 bar, $15 \mathrm{~h}$ of impregnation and 10 bar min $^{-1}$ of depressurization rate). This is a very interesting result for food packaging applications for which it is important to maintain WVP as low as possible, or at least to reduce moisture transfer between food and atmosphere (Souza et al., 2012).

The decrease in WVP data observed for films impregnated by SSI may be due to: (i) the homogeneous dispersion of CN through the matrix including surface, as indicated by SEM, which acts as a barrier against water vapor; (ii) possible rearrangement of starch polymeric chains induced by the SSI process and; (iii) loss of glycerol during the system depressurization, considering its solubility in $\mathrm{scCO}_{2}$ that varies from $44 \mathrm{~g} \mathrm{~m}^{-3}$ of $\mathrm{CO}_{2}$ at 150 bar to $57 \mathrm{~g} \mathrm{~m}^{-3}$ at 250 bar (Sovová, Jez, \& Khachaturyan, 1997). Previous data reported in the literature showed that the WVP of cassava starch based films significantly decreases when lower amount of glycerol is added as plasticizer (Souza et al., 2012).

Taking into account that the $\mathrm{CN}$ impregnated films developed in this work envisage food applications as packages it is important to guarantee that the proposed alternative processing methodology do not alter the water barrier properties of cassava starch films, namely their water vapor sorption and permeability capacities. These values may vary significantly depending on the specific application however typical values range between $(3.81 \pm 0.58) \mathrm{g} \mathrm{mm} \mathrm{m}^{-2} \mathrm{day}^{-1} \mathrm{kPa}^{-1}$ and $(7.81 \pm 0.58) \mathrm{g} \mathrm{mm} \mathrm{m}^{-2}$ day $^{-1} \mathrm{kPa}^{-1}$ (Souza et al., 2012).

\subsection{Water vapor sorption (WVS)}

Water vapor sorption curves (WVS) of the films with and without cinnamaldehyde are shown in Fig. 4. It can be observed that films processed by SSI presented lower water vapor sorption in comparison to the non-processed ones.

ANOVA indicated that impregnation time $\left(t_{i}\right)$ and depressurization rate $\left(d_{r}\right)$ influenced significantly this property (Table 1 ). As impregnation time increases the WVS decreases, whereas at the same $t_{i}$, it increases with the depressurization rate. It can be
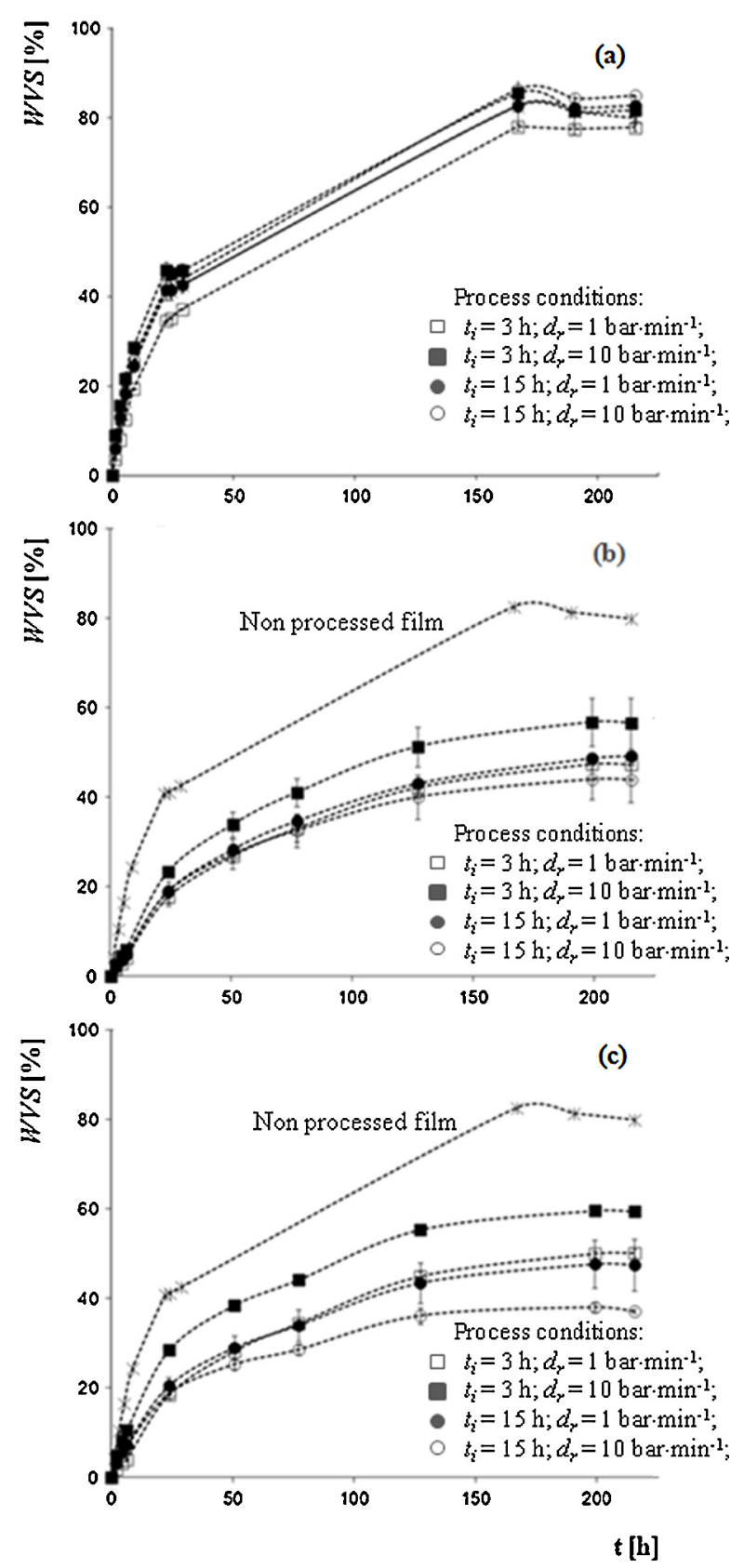

Fig. 4. Water vapor sorption loading of $\mathrm{scCO}_{2}$ processed films at $250 \mathrm{bar}$ (a) and films impregnated with cinnamaldehyde at 150 bar (b) and at 250 bar (c). 
observed in Fig. 4a that the WVS of the films processed with $\mathrm{scCO}_{2}$ at 250 bar achieved the equilibrium after about 9 days $(220 \mathrm{~h})$, presenting values between ( 78 and 85 )\% for all the tested conditions. A significant difference $(P>0.05)$ was observed for films impregnated with $\mathrm{CN}$, which present lower equilibrium water vapor sorption $\left(\mathrm{WVS}_{e}\right.$ ) that ranged from (44 to 57)\% for films processed at $150 \mathrm{bar}$ (Fig. 4b) and from (37 to 59) \% for those processed at 250 bar, after 9 days (Fig. 4c). These values correspond to a decrease of the $\mathrm{WVS}_{e}$ by (30 to 50) \% depending on the $\mathrm{scCO}_{2}$ processing conditions and when compared to non-processed and non-loaded films. These results showed that the impregnation/deposition of cinnamaldehyde into the films increased their hydrophobicity and, consequently, decreased their capacity to adsorb water, which is a significant improvement considering the envisaged applications.

\subsection{Water contact angle}

The higher hydrophobicity of the films impregnated with $\mathrm{CN}$ was confirmed by measuring their surface water contact angles, which were equal to $(55.1 \pm 2.5)^{\circ}$ and $(76.8 \pm 2.1)^{\circ}$ for nonprocessed and $\mathrm{CN}$-impregnated samples, respectively.

\subsection{Thermal analysis}

The effect of the process on the glass transition temperature ( $\mathrm{Tg}$ ) of the films (and indirectly on their flexibility) was accessed by DSC analysis. Data represented in Fig. 5a (thermogram recorded during the first heating) permits to identify two glass transition temperatures around $-25^{\circ} \mathrm{C}$ and $45^{\circ} \mathrm{C}$, with the lowest probably indicating phase separation between the starch-rich and the glycerol-rich phase, as previously reported by Forssell, Mikkilti, Moates, \& Parker, 1997. The second $\mathrm{Tg}$ is between the average values previously reported by the authors (Souza et al., 2012) probably because of the larger amount of glycerol that was used to compensate possible glycerol removal during $\mathrm{scCO}_{2}$ processing. These $\mathrm{Tg}$ values are identified for all samples indicating that processing did not significantly affect the thermal properties of the films. This relatively high $T g$ values, considering the final application, and the tenuous transitions detected are because samples were stored at relative humidity of $\sim 20 \%$ before measurements to reduce the plasticizing effect of water (Mali, Sakanaka, Yamashita, \& Grossmann, 2005; Perdomo et al., 2009). Data recorded during the second heating run (Fig. 5b) shows that the melting temperatures $(\mathrm{Tm})$ increased from $173.16^{\circ} \mathrm{C}$ for the non-processed and non-impregnated samples to $177.63^{\circ} \mathrm{C}$ for the $\mathrm{scCO}_{2}$ processed sample (at 250 bar during $15 \mathrm{~h}$ and with highest depressurization rate of the $10 \mathrm{bar} \mathrm{min}^{-1}$ ) and decreased to $133.69^{\circ} \mathrm{C}$ for the sample impregnated with $\mathrm{CN}$ at the same experimental conditions. These results show that $\mathrm{scCO}_{2}$ processing did not significantly affect the melting temperature of the sample and induced a slight decrease ( $12.5 \%$ ) of the associated enthalpy, $\Delta \mathrm{Hm}$ (that changes from $77.6 \mathrm{Jg}^{-1}$ to $67.9 \mathrm{Jg}^{-1}$ ). This decrease indicates that the process may induce a reorganization of the polymer chains meaning that dissolved $\mathrm{CO}_{2}$ besides induce swelling of the amorphous structure, may also lead to a reduction of the size of the crystalline domains. This information is consistent with that previously reported by Muljana, Picchioni, Heeres, \& Janseen, 2009 when studying the effect of $\mathrm{scCO}_{2}$ on the gelatinization of potato starch. When comparing with $\mathrm{CN}$-loaded samples, a significant decrease in the $\mathrm{Tm}$ is observed $\left(\sim 40^{\circ} \mathrm{C}\right)$ which may indicate that the presence of $\mathrm{CN}$ interrupted the rearrangement of polymer chain due to the bulky benzene structure of the molecule. In this case, the melting endothermic peak seems to be completely overlapped with that corresponding to water evaporation and, therefore, $\Delta \mathrm{Hm}$ was not calculated in this case. However it is important to refer that the peak correspondent to bounded-water evaporation (that was observed at $132.95^{\circ} \mathrm{C}$ as confirmed by TGA, data not shown)

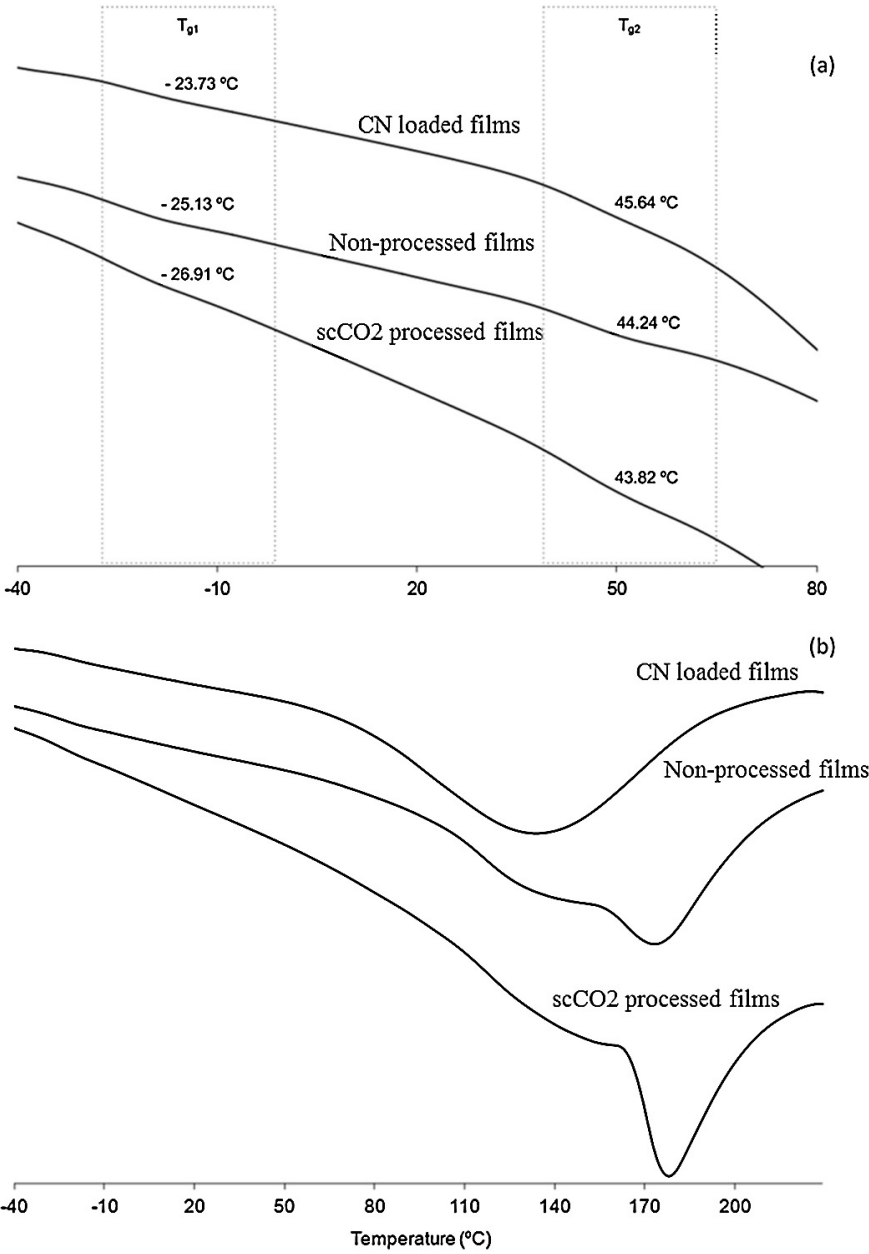

Fig. 5. DSC thermograms of cassava starch based films obtained during the first (a) and second (b) heating steps impregnated with cinnamaldehyde in comparison with non-processed films and $\mathrm{scCO}_{2}$ processed films at the same experimental conditions (pressure of 250 bar during $15 \mathrm{~h}$ and at the highest depressurization rate of the 10 bar min $\left.{ }^{-1}\right)$.

appears at a lower temperature since loaded samples absorb lower water amounts as previously discussed.

\section{Conclusions}

The main objective of this work was successfully achieved since biocomposite films based on cassava starch were incorporated with an antimicrobial agent (cinnamaldehyde) using supercritical solvent impregnation originating active films with good properties for the envisaged applications. The highest $\mathrm{CN}$-impregnated amount $(2.49 \pm 0.30) \mathrm{mg}_{\mathrm{CN}} / \mathrm{g}_{\text {film }}$ was obtained at higher pressure (250 bar), higher impregnation time $(15 \mathrm{~h})$ and at higher depressurization rate ( 10 bar min $^{-1}$ ) indicating that the solubility of $\mathrm{CN}$ in $\mathrm{scCO}_{2}$ is the main factor ruling the impregnation process. However all the other tested conditions permitted to impregnate an amount of $\mathrm{CN}$ that previously proved to inhibit $P$. commune growth. Moreover it was found that the best impregnation condition also lead to a significant decrease in the films water vapor permeability that changed from $(10.09 \pm 0.35) \mathrm{g} \mathrm{mm} \mathrm{m}^{-2} \mathrm{day}^{-1} \mathrm{kPa}^{-1}$ for the non-processed films to $(4.09 \pm 0.84) \mathrm{g} \mathrm{mm} \mathrm{m}^{-2} \mathrm{day}^{-1} \mathrm{kPa}^{-1}$, for $\mathrm{CN}$-loaded films. The equilibrium water vapor sorption capacity of the loaded films was also significantly decreased due to an increase of the surface films hydrophobicity. The results establish that films based on plasticized cassava starch reinforced with clay nanoparticles and incorporated with cinnamaldehyde can be considered 
as an interesting biocomposite alternative packaging material. All together these results are encouraging and suggest that SSI may be an interesting alternative to process cassava starch based films when compared with conventional methods.

\section{Acknowledgements}

This research was supported by FAPESP (The State of São Paulo Research Foundation), process number 2006/068169. A.M.A. Dias acknowledges FCT-MCTES for her fellowship SFRH/BPD/40409/2007.

\section{References}

ASTM Standard E 96/E 96M-10. (2010). Standard Test Methods for Water Vapor Transmission of Materials. In ASTM International West Conshohocken, PA, USA.

Bakkali, F., Averbeck, S., Averbeck, D., \& Idaomar, M. (2008). Biological effects of essential oils: A review. Food Chemistry Toxicology, 46, 446-475.

Baseri, H., Haghighi-Asl, A., \& Lotfollahi, M. N. (2010). Effects of operating parameters on the cinnamaldehyde content of extracted essential oil using various methods. Chemical Engineering Technology, 33, 267-274.

Bierhalz, A. C. K., Silva, M. A., Sousa, H. C., Braga, M. E. M., \& Kieckbusch, T. G. (2013). Influence of natamycin loading methods on the physical characteristics of alginate active films. Journal of Supercritical Fluids, 76, 74-82.

Braga, M. E. M., Pato, M. T. V., Silva, H. S. R. C., Ferreira, E. I., Gil, M. H., Duarte, C. M. M., \& Sousa, H. C. (2008). Supercritical solvent impregnation of ophthalmic drugs on chitosan derivatives. Journal of Supercritical Fluids, 44, 245-257.

Costa, V. P., Braga, M. E. M., Duarte, C. M. M., Alvarez-Lorenzo, C., Concheiro, A., Gil, M. H., \& Sousa, H. C. (2010). Anti-glaucoma drug-loaded contact lenses prepared using supercritical solvent impregnation. Journal of Supercritical Fluids, 53 165-173.

Costa, V. P., Braga, M. E. M., Guerra, J. P., Duarte, A. R. C., Leite, E. O. B., Duarte, C. M M., Gil, M. H., \& Sousa, H. C. (2010). Development of therapeutic contact lense using a supercritical solvent impregnation method. Journal of Supercritical Fluids, 52, 306-316.

Dias, A. M. A., Braga, M. E. M., Seabra, I. J., Ferreira, P., Gil, M. H., \& Sousa, H. C. (2011). Development of natural-based wound dressings impregnated with bioactive compounds and using supercritical carbon dioxide. International Journal of Pharmaceutics, 408, 9-19.

Du Plooy, W., Regnier, T., \& Combrinck, S. (2009). Essential oil amended coatings as alternatives to synthetic fungicides in citrus postharvest management. Postharvest Biology and Technology, 53, 117-122.

Flores, S., Famá, L., Rojas, A. M., Goyanes, S., \& Gerschenson, L. (2007). Physical properties of tapioca-starch edible films: Influence of film-making and potassium sorbate. Food Research International, 40, 257-265.

Forssell, P. M., Mikkilti, J. M., Moates, G. K., \& Parker, R. (1997). Phase and glass transition behavior of concentrates barley starch-glycerol-water mixtures, a model for thermoplastic starch. Carbohydrate Polymers, 34, 275-282.

Kazarian, S. G. (2000). Polymer processing with supercritical fluids. Polymer Sciences Series C, 42, 78-101.

Kechichian, V., Ditchfield, C., Veiga-Santos, P., \& Tadini, C. C. (2010). Natural antimicrobial ingredients incorporated in biodegradable films based on cassava starch. LWT - Food Science and Technology, 43, 1088-1094.

Kikic, F., \& Vecchione, F. (2003). Supercritical impregnation of polymers. Current Opinion Solid State Materials Science, 7, 399-405.

Kim, H.-O., Park, S.-W., \& Park, H.-D. (2004). Inactivation of Escherichia coli 0157:H7 by cinnamic aldehyde purified from Cinnamomum cassia shoot. Food Microbiology, 21, 105-110.

Mali, S., Sakanaka, L. S., Yamashita, F., \& Grossmann, M. V. E. (2005). Water sorption and mechanical properties of cassava starch films and their relation to plasticizing effect. Carbohydrate Polymers, 60, 283-289.

Mayachiew, P., Devashastin, S., Mackey, B. M., \& Niranjan, K. (2010). Effects of drying methods and conditions on antimicrobial activity of edible chitosan films enriched with galangal extract. Food Research International, 43, 125-132.

Mayachiew, P., \& Devashastin, S. (2010). Effects of drying methods and conditions on release characteristics of edible chitosan films enriched with Indian gooseberry extract. Food Chemistry, 118, 594-601.
Mbeya, J. A., Hoppeb, S., \& Thomas, F. (2012). Cassava starch-kaolinite composite film. Effect of clay content and clay modification on film properties. Carbohydrate Polymers, 88, 213-222.

McHugh, T. H., Avena-Bustillos, R., \& Krochta, J. M. (1993). Hydrophilic edible films: Modified procedure for water vapor permeability and explanation of thickness effects. Journal of Food Science, 58, 899-903.

Muljana, H., Picchioni, F., Heeres, H. J., \& Janseen, L. P. B. M. (2009). Supercritical carbon dioxide $\left(\mathrm{ScCO}_{2}\right)$ induced gelatinization of potato starch. Carbohydrate Polymers, 78, 511-519.

Müller, C. M. O., Yamashita, F., \& Laurindo, J. B. (2008). Evaluation of the effects of glycerol and sorbitol concentration and water activity on the water barrier properties of cassava starch films through a solubility approach. Carbohydrate Polymers, 72, 82-87.

Natu, M. V., Gil, M. H., \& Sousa, H. C. (2008). Supercritical solvent impregnation of poly(E-caprolactone)/poly(oxyethylene-b-oxypropylene-b-oxyethylene) and poly(E-caprolactone)/poly(ethylene-vinyl acetate) blends for controlled release applications. Journal of Supercritical Fluids, 47, 93-102.

Nielsen, P. V., \& Rios, R. (2000). Inhibition of fungal growth on bread by volatile components from spices and herbs, and the possible application in active packaging, with special emphasis on mustard essential oil. International Journal of Food Microbiology, 60, 219-229.

NIST. (2013). National institute of standards technology. Gaithersburg, MD, USA: Chemistry WebBook. Available at: www.webbook.nist.gov Accessed 2.06.13

Oussalah, M., Caillet, S., Saucier, L., \& Lacroix, M. (2006). Antimicrobial effects of selected plant oils on the growth of a Pseudomonas putida strain isolated from meat. Meat Science, 73, 236-244.

Oussalah, M., Caillet, S., Saucier, L., \& Lacroix, M. (2007). Inhibitory effects of selected plant essential oils on the growth of four pathogenic bacteria: E. coli 0157:H7, Salmonella typhimurium, Staphylococcus aureus and Listeria monocytogenes. Food Control, 18, 414-420

Paes, S. S., Yakimets, I., \& Mitchell, J. R. (2008). Influence of gelatinization process on functional properties of cassava starch films. Food Hydrocolloids, 22, 788-797.

Perdomo, J., Cova, A., Sandoval, A. J., Garcia, L., Laredo, E., \& Muller, A. J. (2009). Glass transition temperatures and water sorption isotherms of cassava starch. Carbohydrate Polymers, 76, 305-313.

Priolo, M., Gamboa, D., Holder, K., \& Grunlan, J. C. (2010). Super gas barrier transparent polymer-clay multilayer ultrathin film. Nano Letters, 10(12), 4970-4974.

Reverchon, E., \& Cardea, S. (2012). Supercritical fluids in 3D tissue engineering. Journal of Supercritical Fluids, 69, 97-107.

Seydim, A. C., \& Sarikus, G. (2006). Antimicrobial activity of whey protein based edible films incorporated with oregano, rosemary and garlic essential oils. Food Research International, 39, 639-644.

Sonkaew, P., Sane, A., \& Suppakul, P. (2012). Antioxidant activities of curcumin and ascorbyl dipalmitate nanoparticles and their activities after incorporation into cellulose-based packaging films. Journal of Agricultural and Food Chemistry, 60, 5388-5399.

Sousa, H. C., Gil, M. H. M., Leite, E. O. B., Duarte, C. M. M., \& Duarte, A. R. C. (2006) Method for preparing sustained-release therapeutic ophthalmic articles using compressed fluids for impregnation of drugs, European Patent No 1611877A1 (in English).

Souza, A. C., Benze, R., Ferrão, E. S., Ditchfield, C., Coelho, A. C. V., \& Tadini, C. C. (2012), Cassava starch biodegradable films: Influence of glycerol and clay nanoparticles content on tensile and barrier properties and glass transition temperature. LWT - Food Science and Technology, 46, 110-117.

Souza, A. C., Ditchfield, C., \& Tadini, C. C. (2010). Biodegradable films based on biopolymers for food industries. In M. L. Passos, \& C. P. Ribeiro (Eds.), Innovation in food engineering: New techniques and products (pp. 511-537). Boca Raton: CRC Press.

Souza, A. C., Goto, G. E. O., Mainardi, J. A., Coelho, A. C. V., \& Tadini, C. C. (2013). Cassava starch composite films incorporated with cinnamon essential oil: Antimicrobial activity, microstructure, mechanical and barrier properties. LWT - Food Science and Technology, http://dx.doi.org/10.1016/j.lwt.2013.06.017

Sovová, H., Jez, J., \& Khachaturyan, M. (1997). Solubility of squalane, dinonyl phthalate and glycerol in supercritical $\mathrm{CO}_{2}$. Fluid Phase Equilibria, 137, 185-191.

Veiga-Santos, P., Suzuki, C. K., Nery, K. F., Cereda, M. P., \& Scamparini, A. R. P. (2008), Evaluation of optical microscopy efficacy in evaluating cassava starch biofilms microstruture. LWT - Food Science and Technology, 41, 1506-1513.

Wilhelm, H. M., Sierakowski, M. R., Souza, G. P., \& Wypych, F. (2003). Starch films reinforced with mineral clay. Carbohydrate Polymers, 52, 101-110. 